\title{
Gore calls for action on climate change as Congress stalls
}

[WASHINGTON] The Clinton administration is trying to persuade Congress to implement a $\$ 6$ billion programme of research and tax credits aimed at curbing the growth in US emissions of greenhouse gases. It hopes that scientific evidence of soaring global surface temperatures, as well as a spate of extreme weather events, will provide ammunition for its efforts.

Vice-president $\mathrm{Al}$ Gore last week used a prolonged heatwave and drought in the southern United States, together with flash floods in his home state of Tennessee and forest fires in Florida, as a basis for new attacks on Congress, which is trying to block the programme.

"The evidence of global warming keeps piling up," he told a news conference in Washington on 14 July. "How long is it going to take until people in the Congress get the message?" he added. "People are sweltering out there."

Pausing momentarily to point out that no single weather event can be attributed to global warming, Gore ran through a litany of such events in the United States before unveiling new climate data from the National Oceanic and Atmospheric Administration. These show that the first half of 1998 was the warmest on record, by a considerable margin.

The data indicate that the mean global surface temperature in June exceeded the previous record - set in June 1994 - by $0.4^{\circ} \mathrm{F}$. Global surface temperatures have hit record levels for every month of this year, with the overall mean temperature being $1.3^{\circ} \mathrm{F}$ above average for the period $1880-$ 1997 - a deviation from the average that is 50 per cent greater than ever recorded.

Whatever their scientific significance, both the new data and the drought come at a convenient time for Gore. This summer, the administration faces congressional resistance on several fronts to its relatively modest efforts to slow the growth of US carbon emissions.

For example, a clause added to the House version of the Veterans' Affairs and Housing and Urban Development and Independent Agencies bill would prohibit administration officials from "conducting educational outreach or informational seminars on policies underlying the Kyoto Protocol". Gore describes this as a "gag order", and President Bill Clinton is likely to veto any bill containing it.

A more substantial issue is Congress's reluctance to support the Climate Change Technology Initiative. This is the research and development package proposed by the administration in its February budget for

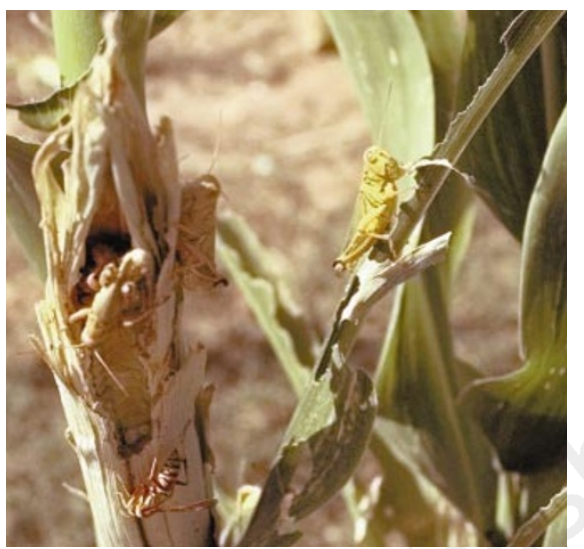

On toast: hungry grasshoppers have descended on Oklahoma's drought-blighted corn crops.

developing technologies to reduce carbon emissions (see Nature 391, 619-620; 1998).

The House Appropriations Committee has removed the additional $\$ 450$ million allocated under the initiative for next year on research into renewable energy sources and energy efficiency technologies. The Senate would allow about one-third of the spending to proceed.

John Holdren of Harvard University, a

member of the President's Council of Advisors on Science and Technology, and author of a 1997 council report recommending the extra spending on energy research, said he was "appalled" by what he called Congress's "sabotaging" of the research programme.

"It's an absurd argument that the initiative is the premature implementation of Kyoto," Holdren says. "Research and development doesn't commit you to meeting an emissions target."

The fate of the Climate Change Technology Initiative - and of the administration's proposal for $\$ 3.6$ billion of tax breaks for energy conservation - will be determined in September, when the budget and tax bills are due to be finalized.

On a more personal level, Gore is almost certain to be the Democrat nominee in the presidential election of 2000, and his longstanding interest in the climate change issue has encouraged strong resistance to action on climate change among the Republicans who control both houses of Congress. "The reality," says one frustrated Democrat staffer on Capitol Hill, "is that anything with Gore's name on it is dead on arrival up here."

ColinMacilwain

\section{Indian atomic chief is refused US visa}

[NEW DELHI] Indian scientists are expressing concern that Washington's decision to refuse the entry of Indian atomic and missile scientists into the United States could affect the free exchange of information between the two countries and set back scientific cooperation.

The US decision was made in response to the nuclear tests conducted by India in May. The Indian warnings follow the denial of a US visa to Rajagopalan Chidambaram, chairman of the Atomic Energy Commission (AEC), preventing him from visiting Atlanta to attend the annual meeting of the International Union of Crystallography, of which he is vice-president.

Chidambaram had applied for a visa not as chairman of the AEC but in his individual capacity as a crystallographer. But the US state department has said that the Clinton administration is reviewing its science and technology engagement with both India and Pakistan after the tests, and that the processing of Chidambaram's visa application was "part of this review process".

Officials in Washington say they have no intention of imposing across-the-board visa restrictions on scientists from either country, and that restrictions will be applied only to individuals engaged in nuclear and missile development.

But Indian scientists fear that the new rules will be extended to scientists in universities or national laboratories whose research may be remotely connected with nuclear or missile development. The US visa policy "will definitely have a nuisance value for us, but we have to accept this as part of life", says Valangiman Ramamurthi, secretary of India's ministry of science and technology.

Chidambaram is not the only top atomic scientist to have been denied a visa by a western country following the Indian nuclear tests. Placid Rodriguez, director of the Indira Gandhi Centre for Atomic Research (IGCAR) at Kalpakkam near Chennai, and his colleague Baldev Raj have both been denied visas to enter Britain. The two researchers had been invited to a Cambridge meeting by a UK publishing company.

In a separate case, Baldev Raj and S. B. Bhoje, director of IGCAR's reactor division, had to abandon planned visits to institutions in Germany after authorities there "suddenly" withdrew their invitations.

K.S. Jayaraman 